\title{
CHANGING FAMILY FORMS: CHALLENGES FOR GERMAN LAW
}

\author{
Nina Dethloff*
}

The diversity of family life is increasing. The rise in unwed parents, divorce rates, re-partnering, same-sex partnerships and artificial reproduction have led to a great variety of family forms that are far apart from the concept of the marriage-based family underlying the German Civil Code of 1900. Despite substantial amendments, the Civil Code in many respects does not correspond to the existing diversity of present-day family forms. A brief outline of the societal changes is followed by an overview of the legal impact of different family forms on children and the key points that are presently under discussion in this field. Subsequently, the changes resulting from the appearance of new partners as potential new parents will be addressed. The current legal situation concerning parental responsibility, as well as its deficits and options for reform, will be reflected upon, mainly with regard to German law. Developments in other countries, particularly in New Zealand, are taken into account.

\section{NEW TYPES OF FAMILIES}

Nowadays families are vastly different from those prevailing when the German Civil Code was enacted in 1900. Over the last few decades, in particular, society and therefore family structures have undergone significant changes: de facto partnerships and divorce are no longer being condemned, but are normal. Same-sex partnerships can be lived freely either formalised as a registered partnership - introduced in 2001 - or not. These changes impact the lives of children: more than 800,000 children grow up in a de facto partnership ${ }^{1}$ and more than 10 per cent of all children below the age of 18 grow up in step, or reconstituted, families. ${ }^{2}$ Many live with same-sex

* Prof Dr Nina Dethloff, LLM, is Director of the Institute for German, European and International Family Law at Rheinische Friedrich-Wilhelms-Universität Bonn. The author wishes to express her gratitude to Dr Luise Hauschild for her valuable assistance in researching and English editing.

1 German Federal Statistics Bureau Bevölkerung und Erwerbstätigkeit: Haushalte und Familien, Ergebnisse des Mikrozensus 2010 (2011) at table 3.1.

2 German Ministry for Families, Senior Citizens, Women and Youths Familien Report 2010 at 23. 
couples, some of which have entered into registered partnerships, while the majority have not. ${ }^{3}$ Reproductive treatments have long since become a common occurrence, especially since there are currently more than two million couples in Germany that are affected by involuntary childlessness. ${ }^{4}$ Every year, 200,000 couples undergo reproductive treatment in Germany while a growing number of people seek medical help abroad. For homosexual couples in particular, such treatments are often the only way to have a child that is genetically related to at least one partner.

With children growing up in vastly divergent families it is no longer clear who their legal parents or holders of parental responsibilities are or should be. This article will examine whether the law is up to the challenges that the increasing diversity of family forms poses and whether it sufficiently protects children in different types of families. It is dedicated to my esteemed colleague and friend Bill Atkin, eminent scholar of family law and advocate of legislation protecting children. ${ }^{5}$

To some extent, the German legislator did react to those societal changes by introducing new provisions, in particular, where the rising number of children born out of wedlock is concerned. Prompted by the European Court of Human Rights and the German Constitutional Court, German law on parental responsibility has been reformed as recently as 2013 to ensure that fathers who are not married to the mother of their child can gain joint custody even against the mother's wishes, provided that this is not inconsistent with the child's best interests. ${ }^{6}$ However, the new law has been severely criticised due to its introduction of an expedited procedure by means of which the court can forego a hearing of the parents, as well as the child and the youth welfare office, and make a custody decision solely based on written accounts. ${ }^{7}$ Nevertheless, the new legislation provides significant improvement, not only of fathers', but likewise of illegitimate children's, rights.

Many other areas of the law remain in dire need of reform, though. In the course of this article, three different types of family will be discussed in regards to the need for reform in Germany, and also in light of developments in other countries, particularly in New Zealand. These are reconstituted families, same-sex families and families created by artificial reproduction. The focus

3 Marina Rupp (ed) Die Situation von Kindern in gleichgeschlechtlichen Lebenspartnerschaften (Bundesanzeiger Verlag, Berlin, 2009) at 28 and following.

4 Bärbel Hüsing and Christoph Revermann Fortpflanzungsmedizin: Rahmenbedingungen, wissenschaftlichtechnische Fortschritte und Folgen (Edition Sigma, Berlin, 2011) at 22.

5 See for instance Bill Atkin "The Care of Children Bill" [2004] NZLJ 44; and his support for vulnerable children: New Zealand Law Society "Legislation to protect vulnerable children needs strengthening" (November 2013) <www.lawsociety.org.nz>.

6 See Katrin Lack "Ein Jahr Gesetz zur Reform der elterlichen Sorge nicht miteinander verheirateter Eltern" [2014] FamRZ 1337; and Luise Hauschild "Germany: Reforming the Law on Parental Responsibility" in Bill Atkin (ed) International Survey of Family Law: 2014 Edition (Jordan Publishing, Bristol, 2014) 147.

7 See further Hauschild, above n 6. 
will be on the issues of parentage as well as the assignment of parental responsibilities to those actually caring for a child.

\section{RECONSTITUTED FAMILIES}

Divorce and separation being on the rise, stepfamilies or reconstituted families are formed, seeing children of one partner living in a household with the new spouse or cohabitant. This new partnership may also be a same-sex partnership, so children may grow up with couples in a registered partnership or a de facto same-sex relationship. ${ }^{8}$ The emotional depth of the child's relationship with their stepparent depends on a number of different factors; primarily the duration of their living together and the child's age at the beginning of their parent's new relationship. The intensity of the child's relationship with its other biological or legal parent may also vary considerably: in some cases the other parent is deceased, unknown or even completely disinterested so that there is practically no contact. On the other hand, particularly when access and visiting rights are exercised regularly or the child lives with both parents for equal amounts of time, the relationship may be very close. In the latter cases, it is possible for a child to grow up with three parents. However, differences in individual cases exist not only in fact but also in law: while parents may have joint parental responsibility, it is also possible that only one parent holds sole parental responsibility. The former is the case in more than 90 per cent of divorced couples as parental responsibility remains joint after the dissolution of the marriage unless otherwise applied for and decided by the court. ${ }^{9}$

\section{A Stepparent Adoption}

Presently, an adoption is the only way for a stepparent to gain full parental responsibility of the stepchild. ${ }^{10}$ Stepparent adoptions are available to spouses and, since 2005, to registered partners. However, it does not usually cater to the child's best interests. ${ }^{11}$ For one, in Germany, stepparent adoption terminates all legal ties - including family relations - to the other parent and their family, such as the child's grandparents or half-siblings. Even in cases of minimal contact, this often contradicts the child's emotional ties. On the other hand, individual motives for stepchild adoption do not always take the child's best interests into account. Many couples do not consider the fact that the adoption constitutes a lifelong legal relationship which prevails even when the marriage of the

8 For further information, see Nina Dethloff "Adoption und Sorgerecht - Problembereiche für die eingetragenen Lebenspartner?" [2010] FPR 208.

9 German Federal Statistics Bureau Familiengerichte 2010 (Fachserie 10, Reihe 2.2, September 2011) at 46 and following, and table 2.8 .

10 Bürgerliches Gesetzbuch [German Civil Code], s 1741(2); and Lebenspartnerschaftgesetz. [Registered Partnership Act], s 9(7).

11 See also Nina Dethloff "From Separation to Stepfamilies" (2015) ZfF 205. 
parent and the stepparent does not. This is an issue that can prove especially problematic. ${ }^{12}$ Claims for child support also persist despite divorce. The possibility to merely grant parental responsibility without the constitution of legal parentage - as designated in many other countries - would do actual child-parent relationships more justice. ${ }^{13}$

\section{$B$ Limited Parental Responsibility of the Stepparent}

A first, if tiny, step towards the legal recognition of social parenthood in Germany has been taken with the introduction of a limited parental responsibility of the spouse in 2001. According to s $1687 \mathrm{~b}$ of the German Civil Code, the spouse of a parent with sole parental responsibility, who is not a parent of the child has the power, in agreement with the parent with parental responsibility, to make joint decisions in matters of the everyday life of the child. Given a closer look, this provision proves insufficient, however, as it depends on sole parental responsibility of the spouse which is only rarely the case. This is due to the fact that, as mentioned above, most couples hold joint parental responsibility after divorce. Furthermore, it is to be expected that the majority of unmarried parents will soon hold joint parental responsibility, following the reform that now enables fathers to be awarded joint parental responsibility by the court, even if the mother does not agree. ${ }^{14}$

When it comes to parental custody powers of the spouse or stepparent, there is no reason why the provision should not apply to cases of joint responsibility. This holds true especially since the stepparent derives their powers from their spouse and those powers are limited to matters of the everyday life of the child. Matters of everyday life, as it stands, do not require both parents' agreement if they live apart. ${ }^{15}$ Therefore, conflicts or deadlock situations are not likely to occur. Furthermore, the provision's scope is too narrow since it applies only to spouses and registered partners. Many couples of reconstituted families are not married, but this does not necessarily mean that the relationship between the stepparent and the child is of a more distant nature.

\section{$C$ Dissolution of the parent's and stepparent's relationship}

The end of the parent's and the stepparent's relationship turns out to be especially challenging regardless of whether the parent and the stepparent separate or divorce, or the parent dies. German law does not allow for a decision in regards to parental responsibility that takes into account the best interests of the child when it comes to the child's relationship with the stepparent. This relationship

12 Nina Dethloff "Biologische, soziale und rechtliche Elternschaft - Herausforderungen durch neue Familienformen und Reproduktionsmedizin" in Herbert Grziwotz (ed) Notarielle Gestaltung bei geänderten Familienstrukturen (NotRV, 2012) 7 at 13 and following.

13 See Nina Dethloff "Kindschaftsrecht des 21: Jahrhunderts - Rechtsvergleichung und Zukunftsperspektiven" [2009] ZKJ 141 at 143 and following.

14 Bürgerliches Gesetzbuch [German Civil Code], s 1626a(1), no 3.

15 See further Karlheinz Muscheler Das Recht der Eingetragenen Lebenspartnerschaft (CH Beck, Munich, 2004) at 444; and Barbara Veit "Kleines Sorgerecht für Stiefeltern (§ 1687b BGB)" [2004] FPR 67 at 70. 
may be closer than the one to the legal and biological parent that has not previously or recently lived with the child. If a biological parent dies, the other biological parent gains sole parental responsibility if they have held joint parental responsibility prior to the death. The other biological parent can then demand that the child be delivered into their care, ${ }^{16}$ even when there is a very close relationship between the child and the stepparent, while there is no or very little emotional connection between the child and its living biological parent. This may be the case, for instance, when the biological parents separated soon after the child's birth.

However, the court may order for the child to remain with the stepparent, at least temporarily. The order can be issued only if the removal of the child would endanger the best interests of the child. ${ }^{17}$ Even if that is the case and the order is granted, the child cannot remain with the stepparent indefinitely. The same holds true when the biological parent loses custody. When the biological parent and the stepparent are cohabitating without being married, the situation is even worse as there is no provision that allows for a court order. The child has to be surrendered to the other parent. There may be a right to contact if the stepparent can be considered a person to whom the child relates closely, or if he or she has or has had actual responsibility for the child (social and family relationship). It is in general to be assumed that actual responsibility has been taken on if the person has been living for a long period in domestic community with the child. ${ }^{18}$

In conclusion, it can be said that ties between the social parent and the child are insufficiently protected by German family law. This makes for an area of law where reforms are needed urgently. It would be most advisable to introduce a provision which allows stepparents, or other third parties involved in the child's care, to obtain some form of full parental responsibility as is the case in New Zealand $^{19}$ and Australia ${ }^{20}$ already. The growing numbers of countries where stepparents can hold parental responsibility offer a wide variety of different models demonstrating how the diverse constellations in reconstituted families can adequately be taken into consideration. ${ }^{21}$

\section{SAME-SEX FAMILIES}

Since the introduction of the Registered Partnership Act (Lebenspartnerschaftsgesetz) in 2001, same-sex couples can enter into registered partnerships. Especially since it was reformed in 2004, there are very few legal differences between a registered partnership and a marriage, most of which have been abolished due to highest-court case law. These developments, as well as the growing

16 Bürgerliches Gesetzbuch [German Civil Code], s 1632(1).

17 Section 1682.

18 Section $1685(2)$

19 Care of Children Act 2004, s 47(1)(c).

20 See only Family Law Act 1975 (Cth), s 65C(c).

21 See Dethloff, above n 11. 
acceptance of same-sex partnerships in German society, have led to our current societal realities in which many children grow up with parents in same-sex partnerships. As far as those children are the biological children of one of the partners, the same rules apply as to other reconstituted families, and the same deficits are to be lamented. The following sections will examine the means that same-sex couples have to jointly realise their desire to have children, like the adoption of a non-biological child as well as assisted reproduction.

\section{A Adoption of a Non-Biological Child}

In Germany, a non-biological child may be adopted by a single person alone or jointly by a married couple. ${ }^{22}$ In contrast, a same-sex couple in a registered partnership cannot jointly adopt a child. Most recently in 2013, the German Constitutional Court found it unconstitutional that the registered partner was not allowed to adopt their partner's previously adopted child while the law allowed for a second parent adoption of the partner's biological child. The Court found that this was in violation of both the children's and the prospective parents' rights of equality; it reasoned that the unequal treatment was not justified as there was no indication that growing up with same-sex parents was in any way detrimental to the child's welfare. ${ }^{23}$

Accordingly, the law has been changed since, ${ }^{24}$ however it still prohibits registered partners to jointly adopt the child in the first place. The current legal situation is just as illogical as it looks on first glance: it is now possible for one partner to adopt a child alone. After the first adoption is finalised, the other partner may adopt the child by way of a second parent adoption. As a result, legally, this has the same effects as a joint adoption. Legislators clearly only changed as much as they were obligated to due to the binding decision of the Court, while the rules for joint adoption, which had not been subject to the constitutional complaint, remained untouched for purely political reasons.

This decision leads to the fact that two sets of adoption procedures are necessary instead of just one. This complication serves no apparent purpose. It is necessary to have a period of personal care, prior to the first adoption, in order to establish a relationship between the child and the prospective adoptive parent. ${ }^{25}$ The court will then consider whether the adoption serves the child's best

22 Bürgerliches Gesetzbuch [German Civil Code], s 1741(2).

23 German Constitutional Court, judgment of 19 February 2013, 1 BvR 3247/09. See for an English translation Bundesverfassungsgericht "Judgment of 19 February 2013" (19 February 2013) <www.bundesverfassungsgericht.de>. See also Luise Hauschild "Abolition of Legal Discrimination and Implication of Highest-Court Case-law" in Bill Atkin (ed) International Survey of Family Law: 2013 Edition (Jordan Publishing, Bristol, 2013) 133.

24 Lebenspartnerschaftgesetz [Registered Partnership Act], s 9(7).

25 Bürgerliches Gesetzbuch [German Civil Code], s 1744. 
interests. ${ }^{26}$ During the investigation preceding the personal care as well as in the court's determination of the child's best interests, the partner of the prospective adoptive parent, as well the child's relationship with that parent, is taken into account. It is therefore not necessary to repeat the assessment during another set of proceedings. Further proceedings are likely to put a strain on the people involved as they will have to take part in another court hearing, and a second set of proceedings will entail further cost. First and foremost, the child is not legally protected until the second adoption is finalised. For instance, they do not have any claims for child support against the second partner.

Due to this, proscription of joint adoption by registered partners is met by the same constitutional objections that have been brought up by the Constitutional Court in its decision cited above. Therefore, as already legal in many other countries, same-sex couples in Germany should be allowed to jointly adopt a child; this would allow the courts to make individual decisions that consider the child's best interests. In light of the recent amendments that have been nothing if not minimal, it is going to take another judgment by the German Constitutional Court to bring these changes about. It would also be a viable option to legalise same-sex marriage so that the provisions limiting joint adoption to married couples would apply to same-sex married couples too, as has been done in New Zealand. ${ }^{27}$

\section{B Stepparent Adoption in the Case of Sperm Donation}

Many same-sex couples wish for a child that is genetically related to at least one of the partners. Lesbian couples may achieve this by way of sperm donation. Men, however, need a surrogate mother to bear the child of one of them.

While, under German law, surrogacy is prohibited, sperm donations are legal. If a child is conceived by means of sperm donation and born into the registered partnership of two women, the partner who did not give birth to the child may only become the child's legal mother by means of stepparent adoption. ${ }^{28}$ This also applies when the partners have made a joint decision to use donor sperm. This legal situation raises fundamental concerns: if heterosexual couples decide to use heterologous-assisted reproduction in order to conceive, the male partner cannot legally contest the child's paternity. ${ }^{29}$ As same-sex couples can become legal parents to a child by means of adoption, it does not make sense to prevent them from becoming parents together upon the child's birth and having to go through the lengthy and complicated process of adoption.

26 Section 1741(1)

27 Marriage (Definition of Marriage) Amendment Act 2013, sch 2, pt 1.

28 Lebenspartnerschaftgesetz [Registered Partnership Act], s 9(7).

29 Bürgerliches Gesetzbuch [German Civil Code], s 1600(5). 
A clear legal assignment of maternity to both mothers upon birth will usually reflect the partners' intention to share responsibility for the child. Even more importantly, this would serve the best interests of the child as a legal relationship to its future social parent would be established upon birth. Such a "co-motherhood" of the biological mother's partner has recently been recognised in a number of countries, such as Spain, the United Kingdom, the Netherlands or the Nordic countries. ${ }^{30}$ In Germany, changes to the law are yet to be made. Looking at those other legal systems, it becomes apparent that maternity is mostly assigned independently of the woman's marital status. A general provision governing legal parentage in cases of assisted reproduction for hetero, as well as samesex, couples in formalised and non-formalised relationships, such as the one introduced to New Zealand law in $2005,{ }^{31}$ would be most commendable. This holds especially true as, in Germany, comotherhood cannot even be legally established by adopting the child when the mothers are not in a registered, but a de facto, partnership.

\section{FAMILIES MADE POSSIBLE BY ASSISTED REPRODUCTION}

Founding a family with the help of assisted reproduction poses significant challenges to which German family law has not risen. It suffers from many deficits in this area, not only in regards to same-sex couples, as outlined above, but also when it comes to heterosexual couples.

\section{A Heterologous-Assisted Reproduction}

\section{Married couples}

Few problems arise when the mother is married at the time of the child's birth: her husband is the legal father of any child born during the marriage, regardless of its actual biological paternity. ${ }^{32}$ This also holds true for cases in which the child has been conceived utilising methods of assisted reproduction, particularly when another man's sperm has been used. If the husband has given his consent prior to the procedure, neither he nor the child's mother can contest the child's paternity in court. ${ }^{33}$ This provision takes into account that the husband's consent has contributed to the conception of the child, therefore he shall not have the means to abandon his parental

30 For Spain, see Ley 14/2006 de 26 de mayo, Sobre Técnicas de Reproducción Humana Asistida; for the United Kingdom, see Human Fertilisation and Embryology Act 2008 (UK); and for the Netherlands see Ian Curry-Sumner and Machteld Vonk "The Netherlands: Dutch Co-motherhood in 2014" in Bill Atkin (ed) The International Survey of Family Law: 2014 Edition (Jordan Publishing, Bristol, 2014) 361. From a comparative perspective, see also Nina Dethloff "Familiengründung gleichgeschlechtlicher Paare in Europa" in Thomas Ackermann and Johannes Köndgen (eds) Privat- und Wirtschaftsrecht in Europa Festschrift für Wulf-Henning Roth zum 70 Geburtstag (CH Beck, München, 2015) 65.

31 Status of Children Act 1969, s 18.

32 Bürgerliches Gesetzbuch [German Civil Code], s 1592, no 1.

33 Section $1600(5)$. 
responsibilities in regards to this child. ${ }^{34}$ However, the child itself is not prohibited from contesting paternity as the German Constitution protects a person's right to know his or her own descent as part of the right to free development of one's personality. ${ }^{35}$ Therefore, the sperm donor may be determined as the legal father by the court, which allows the child to bring child support and inheritance claims against him. This cannot be avoided completely, even by contractual provisions. ${ }^{36}$

It is quite obvious that there is an urgent need to amend these laws: it should not be possible to contest paternity or bring claims against the donor in this particular situation, consistent with the position in most other countries, including New Zealand. ${ }^{37}$ The aforementioned constitutional right to know one's own descent does not make it necessary to allow the child to contest their legal father's paternity and have the donor's paternity determined. Irrespective of status, it is possible for any child to initiate separate proceedings in order to clarify their natural parentage. ${ }^{38}$ For this purpose, it is also essential to guarantee that the donor's personal data is preserved and accessible to the child. At the present time, however, this cannot be ensured as the requirements and legal consequences of assisted reproduction in Germany are not yet comprehensively governed by legislation.

\section{Couples in de facto relationships}

In comparison, the legal situation of couples in de facto relationships is a lot more disadvantageous: the woman's partner does not automatically become the child's legal father even if the couple is cohabitating. Instead, he has to formally acknowledge paternity, which is possible either prior to or after the child's birth. ${ }^{39}$ It remains disputed among scholars and practitioners, however, whether it is possible to acknowledge paternity for a child that has not yet been conceived. ${ }^{40}$ If the partner recognises paternity, as is the case with married couples who mutually decide to use donor sperm, both the legal father and the mother are prohibited from contesting the man's legal parenthood. ${ }^{41}$ If the partner does not recognise paternity for whatever reason, the child

34 Entwurf eines Gesetzes zur weiteren Verbesserung von Kinderrechten of 11 November 1999, BT-Drs. 14/2096, 7 .

35 Grundgesetz für die Bundesrepublik Deutschland [Basic Law for the Federal Republic of Germany], art 2(1) in conjunction with art 1(1).

36 Jochen Taupitz "Die Samenspende: Finanzielles Vabanquespiel für den Spender" [2011] ZRP at 161.

37 Status of Children Act 1969, s 21(2).

38 Bürgerliches Gesetzbuch [German Civil Code], s 1598a.

39 Section 1594.

40 See Nina Dethloff Familienrecht (CH Beck, Munich, 2012) § 10 at 85 for further references.

41 Bürgerliches Gesetzbuch [German Civil Code], s 1600(5). 
lacks sufficient legal protection in this regard. Since the mother's partner is not the child's genetic father, he cannot be determined as the child's father by the court. Therefore it is possible to evade legal responsibility for a child that has been conceived in mutual agreement. The donor, however, can be determined as the father with all the legal and financial consequences this entails. ${ }^{42}$ Since, in these cases, no legal paternity has been established in the first place, the donor is in even greater danger of being held liable. This shows that a different legal framework is needed in order to meet the requirements of this situation. Like New Zealand's law, ${ }^{43}$ German law should assign legal paternity to the woman's partner regardless of whether they are married or simply cohabitating, as long as the decision to resort to homologous insemination has been made mutually. This would not only bring greater security for the child, but would also serve to protect the donor from being held liable for child support.

\section{Same-sex couples}

As outlined above, the legal situation for same-sex couples is even more precarious since the partner has no means of becoming a legal parent upon the child's birth. If the partners have not entered into a registered partnership, the biological mother's partner does not even have the option of stepparent adoption. This means that the child is left with only one legal parent, which can be highly problematic as it entails the consequences outlined above, especially in the event of the end of the parents' relationship.

\section{B Surrogacy}

Finally, both heterosexual and same-sex couples can fulfil their wish for a child by means of a surrogate mother. Surrogacy is prohibited in Germany, ${ }^{44}$ so couples seek help abroad, for example in the United States, Canada or the Ukraine, and within Europe, in the United Kingdom or Greece. If certain requirements are met, the intended parents become the child's legal parents instead of the surrogate who gives birth to the child. But who are the legal parents of that child, according to German law, if the intended parents return to Germany with the child? The answer to that question is currently much disputed. ${ }^{45}$ It first has to be determined which law governs legal parentage. If the intended parents' legal parenthood is established by a decree, the court's decision has to be recognised in Germany in order for them to gain legal paternity under German law. ${ }^{46}$ A foreign

42 Section 1600d.

43 Status of Children Act 1969, s 18 .

44 Embryonenschutzgesetz [Embryo Protection Act], s 1(1), no 7.

45 Katarina Trimmings and Paul Beaumont (eds) International Surrogacy Arrangements (Hart Publishing, Oxford, 2013); and Laurence Bruneta and others A Comparative Study on the Regime of Surrogacy in EU Member States (European Parliament, PE 474.403, 2013).

46 Familienverfahrensgesetz (FamFG) [Family Procedural Act], s 108. 
decree is recognised regardless of the law which has been applied by the court. However, many German courts have considered court decisions that determine parentage for children born through surrogacy in violation of the German public policy (ordre public) in which case recognition is denied. ${ }^{47}$ It has been highly controversial whether this is actually the case. Given the necessity to protect the child, and the fact that it does not have any other legal parents in the country whose courts made the decision, this would have dire consequences for the child. Also, after the child is already born, there is no longer any need to take into consideration the reasons that have led to the prohibition of surrogacy in the first place. On the contrary, it would not be in the best interests of a child that has been born by no fault of its own, using a method which is legally prohibited or ethically frowned upon, to be denied a legal connection to its intended parents just because the government is trying to prevent the usage of surrogacy abroad on a general scale. ${ }^{48}$ In an eagerly awaited judgment Germany's Federal Supreme Court has now confirmed this view. ${ }^{49}$

If the parentage is established by law upon or before the birth of the child, according to German private international law, the law applicable to the child's descent is that of the country in which the child has his or her habitual residence. ${ }^{50}$ If this is Germany, the intended parents will not be considered the child's legal parents, but the surrogate mother and her husband are. The intended mother can only become the child's legal mother by way of adoption. ${ }^{51}$ The intended father can recognise paternity regardless of whether he is genetically related to the child, if the surrogate mother is not married. If the intended father is the child's genetic father, he can also be determined as its legal father by the court. ${ }^{52}$ Even though surrogacy will likely remain illegal in Germany, German legislators should consider the introduction of a facilitated procedure that would allow for the intended parents of a child born through legitimate surrogacy abroad to be determined as its legal parents. ${ }^{53}$

\section{CONCLUSION}

In conclusion, German family law, at present, does not adequately accommodate the changes modern society has undergone. There is great diversity in family structures: heterosexual or samesex couples who assume responsibility for children in marriages, registered partnerships or de facto relationships; and children who are conceived naturally or by methods of assisted reproduction, and

47 Section 109(1), no 4.

48 See Nina Dethloff "Leihmütter, Wunscheltern und ihre Kinder" [2014] JZ 922 at 926.

49 See Federal Supreme Court judgment of 10 December 2014, XII ZB 463/13.

50 Einführungsgesetz zum Bürgerlichen Gesetzbuch (EGBGB) [Introductory Act to the Civil Code], art 19(1).

51 Lebenspartnerschaftgesetz [Registered Partnership Act], s 9(7).

52 Bürgerliches Gesetzbuch [German Civil Code], s 1600d.

53 See Dethloff, above n 48, at 922. 
are related to both, only one or none of the two (or more) people they are raised by. This wide range of possibilities when it comes to modern family life cannot be managed by contractual designs alone.

As it is, German law requires a number of fundamental reforms in order to be able to provide custom-fit solutions for changing family forms. This requires a careful evaluation of the facts, interdisciplinary work and solid comparative legal research. In particular, the innovative approaches New Zealand's legislators have chosen could be of great value in this undertaking, or even serve as an example. Only careful analysis can provide a convincing answer to the question of who shall be a child's legal parents. In this context, it will have to be determined whether, under certain circumstances, a child should be able to have not only two, but three legal parents, as is the case in some countries already. ${ }^{54}$ It would also be of great importance to examine which requirements would have to be met in order to provide legal protection for social parents by granting them full parental responsibility or guardianship. The paramount goal, however, has to be the most effective protection of children, regardless of which type of family they grow up in.

54 Family Law Act S BC 2011 c 25; and Cal Fam Code § 3040(d). 